\title{
Factors affecting male infertility
}

\author{
P. R. Pant \\ Department of Obstetrics and Gynaecology, Institute of Medicine Maharajgunj, Kathmandu, Nepal. \\ Correspondence to: Dr Padam Raj Pant, Department of Obstetrics and Gynaecology, Institute of Medicine Maharajgunj, \\ Kathmandu, Nepal. \\ Email: padam2060@hotmail.com, padam2060@yahoo.com
}

\begin{abstract}
Introduction: Infertility is commonly defined as the failure of conception after at least 12 months of unprotected intercourse. ${ }^{1}$ Accurate assessment of the prevalence of infertility has always been difficult because of the large scale population based studies. ${ }^{2}$ Male factor is the only cause of infertility in about $20 \%$ of infertile couples, but it may be a contributing factor in as many as $30 \%$ to $40 \%$ of cases. ${ }^{3}$ Factors like diabetes, bronchiectasis, high grade fever, long term medication, urinary tract infection, sexually transmitted infection, epididymitis, testicular injury, un-descended testis, mumps, orchitis, excessive alcohol, smoking, exposure to heat and certain chemicals effect in the spermatogenesis. Impotence or erectile dysfunction remains one of the important contributors in the male infertility.

Methods: This is a prospective descriptive study conducted during the health camps in Sindhupalchowk, Manang, Baitedi, Rauthat and Darchula districts of the Nepal. The objective of the study is to find out the factors contributing to male infertility. Couples who were unable to conceive after regular, unprotected coitus of at least one year were included in the study. Detail history, clinical examination and semen analysis was done.

Results: There was limited facility of investigation and treatment of infertility in the health camps. The diagnosis was based only on history, examination and semen analysis. Various factors like mumps, chemical exposure like men working in carpet factory, testicular trauma and smoking were found as contributing factor of male infertility in these districts.

Conclusions: Testicular trauma, mumps, smoking is common in all the districts. Exposure to chemicals such as dyes, used in carpet factories seems to be responsible for infertility in some men of Sindhupalchowk and Darchula.
\end{abstract}

Keywords: Azospermia, male infertility, oligospermia.

\section{Introduction}

Infertility is commonly defined as the failure of conception after at least 12 months of unprotected intercourse. Accurate assessment of the prevalence of infertility has always been difficult because of the large scale population based studies. ${ }^{1}$ Male factor is the only cause of infertility in about $20 \%$ of infertile couples, but it may be a contributing factor in as many as $30 \%$ to $40 \%$ of cases. $^{2}$

In the simplest term male infertility is a failure to fertilize the normal ovum arising from a deficiency of functionally competent sperm at the stage of fertilization. Reports suggest that some 14-17\% of couples may be affected at some time in their reproductive lives. ${ }^{3}$ According to recent European data one of the four couple has infertility problems. ${ }^{4}$ Most of the studies which have attempted to evaluate the etiology of infertility have used the conventional criteria of semen quality promulgated by the WHO (1999) to define male factor. WHO criteria of semen analysis is important but many of the couple are able to conceive even with these abnormal semen findings. ${ }^{5-7}$ Diagnostic categories for the male partner of an infertile couple according to WHO remains of basic importance. ${ }^{8}$ The idiopathic causes are, oligospermia, asthenozoospermia, teratozoospermia, azospermia etc. 
Others are obstructive azospermia, isolated seminal abnormalities sexual or ejaculatory dysfunction. Systemic diseases, endocrine abnormalities, iatrogenic injuries, congenital abnormalities, acquired testicular damage, vericocele, immunological factors, male accessory gland infection etc are also responsible for male infertility.

\section{Methods}

A prospective observational study was conducted in reproductive health camps of Sindhupalchowk, Manang, Baitadi, Rauthat and Darchula district.

In the camps the couples who presented with history of inability to conceive after regular, unprotected coitus of at least one year were called separately at the end of the day for detail history taking, examination, counseling and investigations. After mass counseling, verbal consent was taken for enrollment in the study. All the couples agreed to participate in the study. Their detail history focusing on above mentioned causes was taken and thorough examination for general physical and systemic abnormalities was done.

Unfortunately there was limited investigation facility. Only history, examination and semen analysis were basis of this research.

After semen analysis and counseling, couples were advised to attend the infertility clinic nearest to their place for possible management

\section{Results}

Smoking, testicular trauma and mumps were the common risk factors amongst the males of infertile couples (Table 1).

Table 1: Risk factors of infertility

$\begin{array}{llllll} & \text { Sindhupalchowk } & \text { Manang } & \text { Baitadi } & \text { Rauthat } & \text { Darchula } \\ \text { Mumps } & 1 & 2 & 2 & 2 & 1 \\ \text { Heat Exposure } & 2 & - & 1 & 1 & 1 \\ \text { Testicular trauma } & 1 & - & 1 & 1 & 2 \\ \text { High grade fever } & - & - & - & - & - \\ \text { Tuberculosis } & - & - & 1 & 2 & - \\ \text { Chemical } & & & & & \\ \text { Exposure } & 5 & - & - & - & 4 \\ \text { Smoking } & 4 & - & 4 & 6 & 5 \\ \text { Alcohol } & 2 & 5 & 1 & 1 & 1 \\ \text { Undescended } & \text { testis } & 1 & - & 1 & 1 \\ \text { Diabetes } & - & - & - & - & - \\ \text { Sexually transmitted disease } & - & - & - & - \\ \text { Hydrocele } & 2 & - & 1 & 3 & 1 \\ \text { Varicocele } & - & - & - & 1 & - \\ \text { Multiple risk factors3 } & 3 & 2 & 4 & 3\end{array}$

Mumps seems commoner in all the four districts, chemical exposure is only in Sindhupalchowk and Darchula districts. All of them were exposed to the carpet dyes which are quite common in Darchula and men from Sindhupalchowk were also working in carpet industries in Kathmandu. Many of the patients had multiple risk factors.

Table 2: Proportion of male infertility in relation to total gynaecological and infertility patients.

Proportionally men are most affected in Sindhupalchowk district, where the male factor is responsible in $25 \%$ of infertility (Table 2).

\begin{tabular}{|c|c|c|c|c|c|}
\hline \multicolumn{2}{|c|}{ Sindhupalchowk } & Manang & Baitadi & Rauthat & Darchula \\
\hline \multicolumn{6}{|l|}{ Total Gynae } \\
\hline $\begin{array}{l}\text { Infertile patients } \\
\text { Infertility patient }\end{array}$ & $64(15.2 \%)$ & $24(5.9 \%)$ & $58(12.6 \%)$ & $109(11.49 \%)$ & $86(11.42 \%)$ \\
\hline with male factors & $16(25 \%)$ & $5(20.8 \%)$ & $11(18.9 \%)$ & $21(19.2 \%)$ & $17(19.76 \%)$ \\
\hline
\end{tabular}

None of the patients had isolated abnormal motility but there was oligospermia associated decreased motility in some patients (Fig. 1).

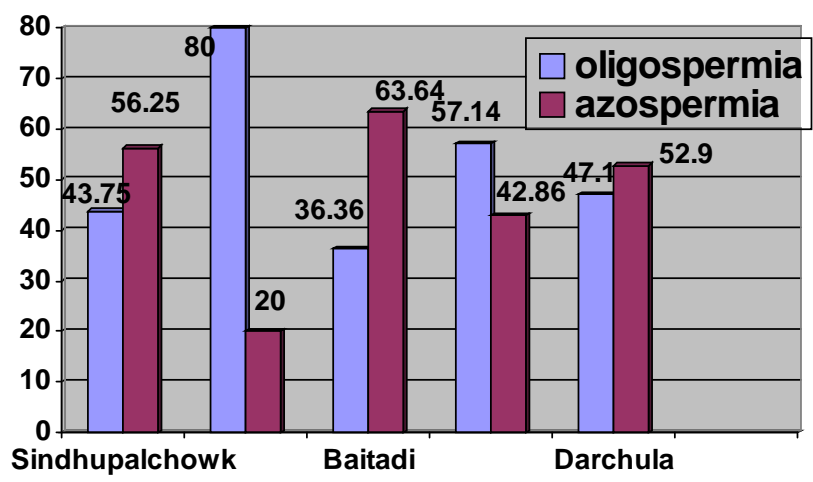

Fig. 1: Sperm abnormality in different districts (\%)

\section{Discussion}

As already said above, accurate assessment of the prevalence of infertility has always been difficult because of the large scale population based studies. According to the study by Hull et al, some 14-17 percent of couples may be affected at some time in their reproductive lives, according to another study by Thonneau LS, male factor is the only cause of infertility in $20 \%$ of the couple, but it may be a contributing factor in as many as $30 \%$ to $40 \%$ of cases. ${ }^{9}$ In this study the highest percentage of infertile couple were in Sindhupalchowk (15.2\% of total gynaecological patients with $25 \%$ of male factors) and least in Manang (5.9\% infertile couple of total gynaecological patients with $20.8 \%$ male factors).

For men semen analysis is inexpensive and noninvasive and remains fundamental to the infertility evaluation. In this study only history, examination and semen analysis 
was the basis as there were no other facilities in these camps.

As evident from the result mumps was found to be a contributing factor in all five districts, heat exposure and testicular trauma was found in the districts except than the Manang. Chemical exposure was the main from Sindhupalchowk and Darchula who work in carpet industries; probably they were working with carpet dye. Hydrocele was found in all districts except in Manang. According to Comhair, varicocele contributes $48 \%$ cases but surprisingly in this study only one case was found with varicocele in Rauthat.

Alcohol was consumed by some men in every district but it was consumed by majority in Manang probably due to cold climate, but none of the men was found smoker among the infertile couple. Oligospermia was found maximum percentage in Manang while Azospermia in Baitadi district.

Unfortunately for complete diagnosis of these couple other tests like immunological tests, testicular biopsy, and hormone profiles could not be done in the camps.

\section{Conclusions}

Alcohol intake and smoking was very common in the couples with infertility. Exposure to dyes (especially carpet dye) was a common incidence among them. Though Testicular trauma, mumps and hydrocele was also common among the infertile males, further studies and more detail investigations which is beyond the scope of a health camp is required to establish a definite association.

\section{Acknowledgement}

I am very grateful to Dr Bhim Singh Tinkari, Dr Shyam Sundar Mishra, Dr Bhoj Raj Joshi, Prof Dr K P Singh, Prof Dr Deepak Mahara Dr Nil Raj Sharma, Vinaya Lama, Dr Bindu Wagle and other team members of health camps in different districts and the clients who were enrolled in the study.

\section{References}

1. Irvin DS. Epidemiology and etiology of male infertility. Human Reproduction 1998;13(1):33-44.

2. Thonneau P, Marchand S, Tallec A. An Incidence and main causes of infertility in a resident population (1.850, 000) of three French regions (1988-1989). Hum Reprod 1991;6;811-16.

3. Hull MGR, Glazener CMA, Kelly NJ. Population Study of causes, treatment and outcome of infertility. British Medical Journal. 1985;291:1693-97.
4. Schmidt L, Munster K, Helm P. Infertility and the seeking of infertility treatment in a representative population.

British Journal of Obstructers and Gynaecology, 1995;102:978-84.

5. Irvine DS, Aitken RJ. Seminal fluid analysis and sperm function testing. Endocrinology and metabolism Clinics of North America. 1994;23:725-48.

6. Aitken RJ, Best FSM, Richardson DW. An analysis of sperm function in cases of unexplained infertility: conventional criteria, movement characteristics, and fertility capacity. Fertility and Sterility. 1982;39:212-21.

7. Aitken RJ, Best FSM, Richardson DW, Djahanbakhch $\mathrm{O}$, Templeton A. Lee MM. An analysis of semen quality and sperm function in cases of oligozoospermia. Fertility and sterility. 1982; 38: 705-711.

8. Rowe PJ, Combhaire FJ, Hargreave TB, Mellows HJ. WHO manual for the standardized investigation and diagnosis of the infertile couple. Cambridge University press, Cambridg. 1993.

9. Thonneau P, Marchand S, Tallec A. Incidence and main causes of infertility in resident population $(1850,000)$ of three French regions (1988-1989) Hum. Reprod. 1991;6:811-816.

10. Comhaire FH, De Kretser D, Farley TMM. Towards more objectivity in diagnosis and management of male infertility: Results of a World Health organization multicentre study. International Journal of Andrology 1987;10 (S7):1-53. 